\title{
VALUACIÓN BIOÉTICA DEL PROYECTO "GENOMA HUMANO"
}

Leonides Santos y Vargas.*

Resumen: Este texto propone una serie de reflexiones que se desprenden de los recientes progresos acaecidos en las investigaciones sobre el Proyecto del Genoma Humano, los cuales conducen al fortalecimiento acelerado de conocimientos y tecnologías biomédicas. Las nuevas afirmaciones sobre la naturaleza biológica de la especie humana, legitimadas por estos nuevos progresos, posibilitan reexaminar explicaciones mitológicas y metafísicas acumuladas desde hace milenios, en el contexto de una nueva antropología filosófica. Los progresos en las intervenciones de la ciencia médica sobre la salud y la calidad de la vida humana permiten evaluar nuevamente la legitimidad de una serie de nuevas posibilidades biomédicas. Es así como este texto aborda también, de manera particular, la temática de la clonación y de sus distintos aspectos económicos y políticos.

Palabras clave: Bioética, genoma humano, biomédica, antropología filosófica, clonación

\section{BIOETHICAL VALIDATION OF THE «HUMAN GENOME PROJECT»}

\begin{abstract}
This text proposes a number of reflections that issue fron the recent advancements that have taken place in investigations on the Human Genoma Project, which lead to the accelerated reinforcement of biomedical knowledge and technologies. The new statements upon human species' biological nature, legitimated by these new progress, allow us to reexamine the mythological and metaphysical explanations accumulated for millenia, facing a new philosophical anthropology. The advancements of medical science's interventions upon health and quality of life, allow us to evaluate again the legitimateness of a quantity of new biomedical possibilities. This text touches, too, in a particular way, the subject of cloning and it's different economic and political aspects.
\end{abstract}

Keywords: Bioethics, human genome, biomedical, philosophical anthropology, cloning

\section{AVALIAÇÃO BIOÉTICA DO PROJETO “GENOME HUMANO”}

Resumo: Este texto propõe reflexões sobre os recentes progressos apresentados pelas investigações decorrentes do Projeto Genoma Humano que conduzem a sólidos conhecimentos em tecnologias biomedicas. As novas informações sobre a natureza da espécie humana obtidas por esses avanços permitem re-examinar explicações mitológicas e metafísicas acumuladas por milênios através da ótica da antropologia filosófica. Os progressos nas intervenções da ciência sobre a saúde e qualidade de vida humana permitem avaliar a legitimidade de uma série de proposições biomédicas. Nesse sentido, o presente texto apresenta reflexões sobre o tema da clonagem e seus diferentes aspectos econômicos e políticos.

Palavras chave: Bioética, genoma humano, biomedicina, antropologia filosófica, clonagem

\footnotetext{
* Ph. D. Director del Instituto de Estudios Humanísticos y Bioética «Eugenio María de Hostos». Recinto de Ciencias Médicas, Universidad de Puerto Rico.

Correspondencia: leosanvar@yahoo.com
} 
Valuación bioética del proyecto "genoma humano" - L. Santos y Vargas

\section{Significado histórico del Proyecto Genoma Humano (PGH)}

El Proyecto del Genoma Humano (PGH) se inició en los Estados Unidos en el año de 1992 con los objetivos siguientes: 1) cartografiar, es decir preparar el mapa del genoma humano y 2) secuenciar el ADN de los cromosomas de dicho genoma. Simultáneamente con esos objetivos, se desarrollarían métodos computacionales rápidos y sofisticados que permitieran acelerar el proceso de secuenciación y cartografiado del genoma. Además de los EEUU, han participado en el PGH otras naciones con infraestructura científica desarrollada, entre los cuales cabe mencionar a Inglaterra, Alemania, Japón, España y Francia. Originalmente se pensaba que el genoma humano tendría un total aproximado a los 80000 o 100000 genes. Los resultados informados recientemente parecen indicar que es probable que el total de genes no exceda de entre 30000 a 50000 . Todavía no se tiene la información definitiva.

Este proyecto es, a mi modo de ver, el más ambicioso de todos los que se ha propuesto la curiosidad científica hasta el presente. El contenido e importancia de los datos cuantificados del proyecto del genoma humano ha llevado a algunos comentaristas a caracterizarlo como el "Libro de la vida", el "Santo Grial" de la biología, el "Manual del hombre", el "Código de los códigos", el "Plan maestro de la vida", en fin, una serie de nombres con los cuales se quiere dramatizar el significado histórico del intento de penetrar los reinos insondables de lo que todavía muchos consideran debe ser la prerrogativa exclusiva de los dioses. La sentencia de la serpiente mitológica del Edén, en la cual se asegura a la primera pareja que Eritis sicut dei, tiene visos de realización a punto de consumarse. No que sereis dioses sino como dioses. Es decir, sereis unos símiles de dioses.
Y la verdad es que una vez que las investigaciones que recién han comenzado logren interpretar, constatar, identificar y establecer relaciones de causa y efecto entre genes específicos y conjunto de genes, con las condiciones y fenotipos del ser humano, sólo la imaginación creativa y la imaginación moral del homo sapiens pondrán límites al nuevo poder de la ciencia genómica. Pero esto no es sólo cierto con relación al conocimiento del genoma humano sino que también es cierto del desciframiento del genoma animal no-humano y del genoma vegetal, que es otra investigación que corre paralela al PGH.

Todo conocimiento que faculte al ser humano para intervenir y modificar la realidad física, animal, vegetal y la específicamente humana, invita a una reflexión y valuación ética. Esta reflexión es más necesaria en momentos en que muchos sectores sociales han reaccionado tan visceralmente a los hallazgos preliminares. Parecería que las creencias de las personas que integran estos sectores sociales están tan emocionalmente afincadas a sus vidas personales que no pueden trascender las ataduras psicosomáticas que tales creencias les han impuesto. Esa reacción visceral es comprensible toda vez que los datos de la ciencia podrían muy bien contradecir las premisas y doctrinas confesionales que le dan sentido al proyecto histórico de venerables instituciones religiosas.

\section{Explicaciones sobre la vida del cuerpo}

Los avances informados recientemente (desde febrero del 2001) respecto de los objetivos del PGH apuntan, entre otros efectos, hacia el fortalecimiento exponencial de los conocimientos y tecnologías biomédicas. Pero en adición a las implicaciones para la ciencia médica, tales avances prometen proveer nuevas 
pistas para entender objetivamente el origen de la naturaleza biológica de la especie humana. La corporeidad biológica, arropada por una historia de explicaciones mitológicas y metafísicas desde hace varios milenios, por fin tendrá una explicación más sensata y cercana a la que los filósofos escépticos han sospechado.

Reflexionemos en primer lugar sobre algunas implicaciones probables del poder de intervención de la ciencia médica sobre la salud y la calidad de la vida humana y, sobre todo, cómo el conocimiento detallado del genoma humano hace factible la posibilidad de modificar y mejorar la manifestación de la vida en muchas de sus formas. Si se confirman las hipótesis en torno a los usos innumerables de la ciencia genómica, no cabe la menor duda de que al poder curativo de la medicina se le añadirá un mayor poder predictivo. Esto permitirá, a su vez, diseñar planes de tratamiento preventivo literalmente hechos a la medida de la condición y propensiones genéticas de los pacientes. Como consecuencia, los diagnósticos y planes de tratamientos serán más confiables y eficaces que los actuales. La medicina predictiva y la medicina genómica podrían convertirse en nuevas especialidades.

También se puede anticipar que la industria farmacéutica podrá elaborar medicamentos y fármacos a la medida genómica de la persona, lo que, aparte de la mayor eficacia terapéutica, augura una bonanza económica sin precedentes para esa industria. Una vez que se conozca la relación de causa y efecto entre genes y grupos de genes (y quizás la de ciertas proteínas) con las condiciones de salud y propensión a enfermedades, es de esperarse que el arsenal de pruebas y procedimientos diagnósticos actuales disminuya en cantidad, pero que los procedimientos diagnósticos aumenten en precisión. A mayor precisión en el diagnóstico, menor será la necesidad de segundas y terceras opiniones de expertos médicos.
En términos globales, a medida que se descubra la causalidad genética de muchas enfermedades y de condiciones incapacitantes, disminuirá la morbilidad en las poblaciones humanas y se economizarán millones de dólares en servicios de salud, por lo menos en aquellas sociedades desarrolladas que tengan acceso a estos beneficios de la ciencia. Será razonable esperar que en las sociedades más desarrolladas, desaparezcan muchas enfermedades (excepto aquéllas cuya causal reside en el entorno ambiental, como las producidas por virus, bacterias, tóxicos y accidentes, para lo cual se requerirán acercamientos de políticas sociales de prevención y protección). Y destaco lo de «sociedades desarrolladas» pues es evidente que estas iniciativas científicas financiadas por el gran capital sólo beneficiarán prioritariamente a las poblaciones cuyo nivel de ingreso económico está bien distante de la mediana mundial de ingresos y que les permitirá pagar por los nuevos beneficios de la ciencia genómica.

A pesar de que la información preliminar del PGH corrobora el juicio ético de que los seres humanos somos iguales (ya que compartimos una herencia y origen genético común), tal revelación objetiva no eliminará las desigualdades creadas y aprendidas a través del genoma cultural. Habrá que insistir en reeducar a la especie humana para eliminar las taras culturales que son las que, en última instancia, explican las prácticas y discursos de la violencia, la injusticia y la discriminación.

Una de las promesas del conocimiento que, eventualmente, se obtendrá del PGH permitirá realizar la terapia genética. La terapia genética podrá prevenir in utero (y aun antes del útero, al nivel de línea germinal) la expresión de genes que correlacionan directamente con enfermedades, malformaciones e impedimentos. Igualmente se anticipa como probable 
Valuación bioética del proyecto "genoma humano" - L. Santos y Vargas

la aplicación de la terapia somática (medicina genómica), la cual será posible mediante la inserción de genes hasta el interior de las células, utilizando vectores adecuados. Estos vectores transportarán los genes sanos hasta el interior de la célula y una vez allí, se espera que ocurra el reemplazo del gen o genes defectuosos.

La posibilidad de desarrollar la tecnología de modificación de la línea germinal, cuyas modificaciones pasarían a la prole, quizás despierte en algunos sectores de opinión el temor a las antiguas motivaciones de la eugenesia. No hay dudas de que estos nuevos poderes de la ciencia facilitarán la selección de genes que mejoren aquellas características y rasgos de los hijos que se desean tener. La idea del bebé óptimo, ilusión de muchos padres, sería factible si resultaran ciertos estos vaticinios que los futurólogos expresan respecto al nuevo poderío científico a disposición de la imaginación humana.

Otra posibilidad (que produce algunos escozores éticos en ciertas personas) es la capacidad para crear nuevas formas inéditas de vidas, tales como animales y plantas transgénicas, lo que ya se ha hecho a escala industrial en la producción de alimentos genéticamente modificados, y se ha hecho con animales en escala experimental. Como se puede apreciar, la ciencia no sólo cumplirá con su función de descripción, predicción y explicación de los fenómenos que conforman su objeto de curiosidad epistemológica, sino que ahora la ciencia añade el poder de invención de nuevas formas de vida (Eritis sicut dei.). Gracias al nuevo poder de invención, la sociedad dispondrá de animales genéticamente modificados con genes humanos (como cerdos transgénicos) que se criarían a modo de incubadoras de órganos para transplantes futuros. Se prevé que un hígado, riñón o corazón de un cerdo transgénico, el cual tendría genes com- patibles con los de su dueño, servirían como órganos de reemplazo, en caso que el órgano del dueño necesitara ser transplantado.

Este nuevo poder de crear nuevas formas de vida utilizando la capacidad para cruzar las fronteras que la evolución natural de las especies había establecido, sugiere a la imaginación el temor de que algún científico se sienta atraído por la curiosidad de averiguar qué pasaría si se mezclara la información genética de varias especies para crear nuevos seres transgénicos. No es improbable pensar que se produzcan nuevos animales de diseño, como ya hay drogas de diseño. Desde luego, una vez que se pongan a punto estas nuevas tecnologías de la manipulación genética de la vida, será difícil resistir la tentación de recrear la especie humana. Teórica y prácticamente se podrá rediseñar la naturaleza humana misma, recurriendo no a la reingeniería social sino a la reingeniería genética.

\section{La clonación de la vida}

Ya es conocida la discusión reciente sobre la posible clonación de células madres embrionarias. Si se confirman las hipótesis que se han debatido públicamente, respecto a los usos de la clonación de estas células para fines terapéuticos, resultan muy esperanzadoras las posibilidades del uso beneficente del conocimiento genético. Por ejemplo, se presume que mediante el recurso de insertar genes sanos en órganos deteriorados, éstos se podrán regenerar, procedimiento que haría innecesaria la opción del transplante para miles de personas e, incluso, hará innecesario el transplante de órganos transgénicos (los llamados xenotransplantes.) Aunque se han hecho esfuerzos para establecer la distinción conceptual entre clonación terapéutica y clonación reproductiva, es evidente que la fascinación del debate público más reciente está concentrada 
en la eventual clonación reproductiva de la especie humana. Ante las implicaciones éticas, económicas y políticas de estas nuevas biotecnologías, los foros legislativos en las sociedades desarrolladas han tomado nota del asunto. En Inglaterra, por ejemplo, las cámaras legislativas autorizaron la clonación de embriones humanos para propósitos de investigación con fines terapéuticos.

La posibilidad de la clonación reproductiva ha creado tal revuelo en ciertos sectores religiosos, políticos, científicos y comunitarios que, por evitarla, se oponen tajantemente a la clonación terapéutica. Piensan, no sin razón, que una vez se demuestre el potencial positivo de la clonación de embriones, y que la técnica del clonado se haya depurado, será cuestión de tiempo que en algún país del planeta se realice la clonación de un individuo humano completo. No me cabe la menor duda de que la tentación de pasar a la historia como pionero de la clonación humana será irresistible para el laboratorio o científico que lo haga. Las precauciones y advertencias éticas que ahora se debaten, no serán obstáculo a la hubris prometéica de la ciencia y de la empresa económica que la financie.

Personalmente, considero que afirmar dogmática y visceralmente que la clonación reproductiva sea intrínsecamente inmoral, constituye un non sequitur ético. No tengo dificultad en señalar, por otro lado, que debido a lo inseguro de la técnica al día de hoy, sería inmoral intentar la clonación en esta etapa de la investigación. Desde el punto de vista del principio de no-maleficencia, sería un acto inmoral ensayar en humanos técnicas ineficientes o ineficaces que arriesgan la salud y calidad de vida del ser clonado. Pero una vez que se depure y se garantice que no hay daños ni riesgos para el clon, la imaginación y el análisis éticos puede identificar casos y situaciones en los cuales la clonación reproductiva facilitaría el logro de ideales humanos éticamente legítimos (en personas infértiles por ejemplo, o para aquellas personas que son portadoras de genes cuya expresión haría existencialmente incompatible la dignidad y florecimiento humano de los seres humanos por nacer). Veamos algunas instancias en las que la clonación reproductiva parecería éticamente problemática.

El hecho de que una persona elija la dotación genética de otro ser puede ser una forma indebida de dominio sobre el destino del nuevo ser. Debe ser desagradable saber que alguien escogió mis características físicas y en cierta manera determinó parte de mi potencial. Por otro lado, se podría pensar que la clonación reproductiva equivale a una especie de agresión por el hecho que un adulto clonado, en cierto sentido, le va anticipando la biografía al ser clonado.

Saber un clon humano que cuando tenga 60 o más años lucirá físicamente como su original, o que tendrá los problemas y condiciones patológicas de que padece su original, podría generarle ansiedad y depresión. Todo ser humano tiene derecho a no saber, o a ignorar su devenir biológico futuro. Sería doloroso que el clon supiera que cuando llegue a los 30 años padecerá de esquizofrenia (cosa que ya sabe que le ocurrió al ser original del cual es un clon). Claro que si el mal de que sabe padecerá el clon se puede remediar, sería conveniente saberlo de antemano, pero si no hay solución para el mal previsto, sería doloroso saber lo que le espera sin tener la solución disponible.

Los motivos para que una persona opte por clonarse pueden ser éticamente cuestionables. Sería éticamente cuestionable que se produzcan clones como monumentos a la vanidad del que puede pagar el costo de muchos clones que circularán por las calles como testimonio visible de cómo era físicamen- 
te el clonado. No importa que el clonado haya sido un gran filántropo, un prohombre, o mujer célebre por sus hazañas éticas o científicas. Un ser humano no debe nacer como memorabilia, sólo para dar cuenta que se parece a un ser famoso. Tampoco sería éticamente legitimable clonar a un ser humano sólo para que sirva de incubadora de órganos para el original clonado. Quizás sería justificable en algunos casos crear por clonación a un hermano para que done un riñón a su hermano antecesor enfermo, pero ¿sería decididamente inmoral la ablación del corazón o del hígado del clon para salvar a su hermano enfermo?

Desde el punto legal, la posibilidad de la clonación reproductiva crearía posibles distorsiones de las relaciones parentales y de filiación familiar. Por ejemplo, un clon sería hijo social del original o su hermano gemelo; por otro lado, parecería que la esposa del clonado hubiera parido al hermano gemelo de su marido (en cuyo caso parió a su cuñado.)

¿Se debe prohibir la clonación reproductiva? Sostengo que la actitud y énfasis de las sociedades no debe ser la de prohibir sin más, sino exhortar a los científicos a que actúen con responsabilidad. Como hemos dicho anteriormente, debido a lo poco desarrollado de la técnica en estos momentos, sería anti-ético intentar clonar a un ser humano. Pero una vez que se afine la tecnología y se ponga a punto, la clonación puede ser una opción válida para personas infértiles que quisieran tener hijos genéticamente afines.

En lugar de prohibir la clonación de la vida humana, sería más importante y prudente esperar que las sociedades promuevan una cultura de responsabilidad en la investigación científica. Una cultura de responsabilidad establecería que las tecnologías (como la clonación) sólo se aplicarán a seres humanos cuando se esté razonablemente seguro de que tales técnicas no harán daño a las personas que opten por la clonación, ni a la persona del clon.

\section{EI PGH y la constante del interés económico}

En adición a la especulación ético-filosófica que sobre los beneficios para la humanidad implica la realización del PGH, hay una serie de otras preguntas que se plantean a propósito de la manera cómo se va desarrollando el proyecto y en torno a la diversidad de motivaciones que lo impulsan. El PGH es una actividad conjunta de muchos países en la cual participan agencias de diferentes estados, la academia universitaria y una multiplicidad de empresas privadas. El sector empresarial privado participante ve en el PGH una oportunidad dorada para obtener ganancias en cantidades insospechadas. Y no hay dudas de que si el proyecto fructifica como se anticipa; si se descubre el secreto de cómo evitar y curar ciertas enfermedades y cómo evitar malformaciones múltiples en las criaturas por nacer, se abre una oportunidad para grandes negocios biotecnológicos, sobre todo para las empresas fármaco-genómicas.

Basándose en decisiones del Tribunal Supremo de los EEUU tomadas desde 1980 (Diamond vs. Chakrabarty) la Oficina Federal de Patentes y Marcas ha autorizado patentes por el descubrimiento de ciertos genes y secuencias genéticas que se sabe son responsables de la aparición de varias enfermedades. Los médicos y hospitales que desean utilizar esas secuencias para fines diagnósticos, por ejemplo, deben pagar regalías a compañías o individuos dueños de tales patentes por cada vez que utilicen determinadas secuencias genéticas en procedimientos diagnósticos que se sabe son efectivos en identificar la presencia de condiciones y de propensión a enferme- 
dades. En adición a patentar secuencias genéticas con evidente valor médico-comercial, también se ha patentado la invención de animales y plantas transgénicas. Así el llamado oncomouse («oncoratón») patentado por la Universidad de Harvard en 1988, y otros productos de la biotecnología, se han definido como invenciones de la ciencia, y por lo tanto, patentables.

A partir de este momento buena parte de la información del genoma humano, vegetal y animal, no formará parte del patrimonio universal de la humanidad (y ciertamente no será propiedad de los dioses). Muchos animales transgénicos, sustancias, hormonas y secuencias genéticas ya tienen un número de patente, con su correspondiente dueño, quien cobra jugosas regalías por el uso de esa información. La práctica de autorizar patentes de secuencias genéticas específicas, o patentar los procedimientos de combinaciones de genes para crear o modificar formas de vida, sugiere a su vez ciertas interrogantes bioéticas: ¿Es ético patentar genes específicos o secuencias de genes cuya expresión en el organismo se sabe que producen efectos predecibles y, por la tanto, evitables? ¿Es ético patentar lo que ocurre naturalmente? ¿Es ético patentar la vida? Si a nadie se le ocurrió patentar la tabla periódica en química; si a nadie se le ocurrió patentar el descubrimiento del hidrógeno, del helio, o patentar la fuerza de gravedad, ¿por qué permitirlo en el caso de los genes?

Respecto a la eticidad de esa práctica, hay puntos de vista encontrados. Algunos empresarios participantes entienden que es perfectamente legítimo patentar genes específicos o secuencias genéticas con valor diagnóstico o terapéutico comprobado, debido al hecho de que se han invertido millones de dólares en ese empeño. Alegan que los genes, aunque son unidades naturales, de por sí no dicen nada. Se requiere la imaginación científica e inventiva empresarial para poner a buen uso tales descubrimientos científicos.

Ahora bien, ¿no se había dicho por funcionarios políticos y organizaciones mundiales que la información sobre el genoma humano debe ser patrimonio de la humanidad? Eso han dicho, pero independientemente de los pronunciamientos bien intencionados de agencias y grupos que proyectan cierta autoridad moral, la verdad monda y lironda es que el capitalismo empresarial, no se motiva necesariamente por la compasión, por los escrúpulos bioéticos o por lealtades patrióticas. En ese contexto de ideas sería absurdo esperar que el capitalismo biotecnológico se transforme en una actividad desinteresada, sobre todo en vista de una empresa científica repleta de promesas para asuntos tan prioritarios para el ser humano como la salud y la funcionalidad biológica, amén de la posibilidad de la extensión de la vida.

Hace tiempo que en los países con economías de persuasión capitalista, la atención de la salud humana se ha convertido en un negocio muy rentable. Para corroborarlo baste pensar en las miles de industrias farmacéuticas, cadenas de negocios de farmacias, hospitales, oficinas de médicos, audiólogos, dentistas, naturópatas, psiquiatras, psicólogos, etc. De hecho, si en nuestra época la casi totalidad de las manifestaciones de la vida ha sido medicalizada, o se ha convertido en objeto de interés comercial, ¿qué más da que se patente comercialmente la información genética?

El asunto ético no es necesariamente el hecho de que mucho de nuestras vidas se haya medicalizado. Es que parejo con la medicalización se desarrolla la monetarización. Piense usted: si una dama queda embarazada, hay que pagar las pruebas y cuidados prenatales y luego habrá que pagar por nacer. Si el 
bebé no muere al nacer, hay que pagar por cuidados preventivos. ¿Se siente usted triste e infeliz?, eso significa que usted está deprimido, por lo tanto páguele al psiquiatra. Algún psiquiatra pudiera pensar que la "angustia ante la nada" de que hablaban los existencialistas del siglo XX, probablemente no era otra cosa que un caso de depresión profunda. Pero suponga el lector que ante el vacío de la existencia, usted recurra a la trascendencia y decide asistir asíduamente a un lugar en el cual pueda adorar a su dios y pedirle que lo consuele y le dé fortaleza para enfrentar su abandono existencial: deberá pagar usted los diezmos y las ofrendas correspondientes. ¿Quiere que Dios le de prosperidad y le envíe bendiciones en la forma de riqueza material? Escoja usted una de las varias iglesias que predican el Evangelio como si tales iglesias estuvieran cobijadas por alguna sección (sección 936, por ejemplo) del código de Rentas Internas de los EEUU. ¿Quiere ofrecer una misa en memoria, o por el descanso del alma de un ser querido?, pues contribuya usted generosamente a los gastos de la Iglesia. ¿Quiere usted reírse a mandíbula batiente?, páguele al comediante de su gusto. ¿Necesita que le hagan justicia? ¡pague al mejor abogado que encuentre! ¿Quiere hacerse una hipnosis regresiva y descubrir que, entre sus muchas vidas, usted fue una esclava egipcia, o un faraón -o quizás un humilde taíno-, páguele $\$ 500$ por seminario al Dr. Weiss, o la tarifa que cobre cualquier mercachifle de lo esotérico.

En resumidas cuentas, vivir en una sociedad capitalista es toda una empresa económica de por sí. La vida humana, para que valga la pena vivirla en una sociedad capitalista, debe ser costo-efectiva. Por eso es que los pobres ya no son costo-efectivos; por eso es que los ancianos enfermos no son costo-efectivos; por eso es que los ciudadanos con impedimentos no son costo-efectivos; por eso es que la justicia no es costo-efectiva. Lo costo-eficien- te es aquello que genera el máximo beneficio económico con el mínimo de gasto. Un ciudadano que padezca de una condición crónica o catastrófica, no es costo-efectivo. De hecho lo costo-eficiente sería que se muriera lo más pronto posible y que, idealmente, opte por la cremación de manera que no haya que utilizar tierras que se pueden utilizar para fines más rentables.

Ergo, el conocimiento sobre el genoma humano, amén de la hazaña científica que significa, también puede ser una oportunidad para la empresa rentable. Si el ser humano quiere lograr un remedo de inmortalidad biológica con superior calidad de vida (es decir, extender su vida con buena salud mediante la manipulación genética, hasta lograr ciento cincuenta años, por ejemplo, como algunos han sugerido), pues tendrá que pagar. En el siglo de la biología molecular y la medicina genómica, vivir más, vivir saludables y con el mínimo de riesgos genéticos, costará mucho más que vivir en la edad pre-genómica. El mercado hecho fetiche, se ha encargado de reintepretar la valía de lo humano y de la vida en general. La ciencia genómica se convertirá en una empresa económica, lo que implica sofisticados análisis y proyecciones de la ciencia de la economía.

\section{Implicaciones para la investigación y la explicación social de la naturaleza humana}

Una primera implicación que el éxito del PGH podría tener para las ciencias sociales es que de inmediato se le hará muy difícil conseguir financiamiento del estado para proyectos de investigación social. La información que la ciencia social produce no parece ser tan rentable como la información genética que produce la biología molecular. Desde un punto de vista más serio, cabe decir que es muy probable que las ciencias sociales, como modelo 
epistemológico de explicación, se verán obligadas a repensar y matizar muchas de las explicaciones sociales de las costumbres, los hábitos y los usos que se manifiestan en las distintas comunidades humanas. Las ciencias sociales han explicado la naturaleza humana como una de origen esencialmente cultural. Es frecuente que muchos de los rasgos personales se expliquen en función de las experiencias de socialización y aculturación de los individuos que integran la sociedad en cuestión. Este axioma lo resume Ortega y Gasset en su famosos apotegma «Yo soy yo y mi circunstancia». Sobre la base de las circunstancias sociales se explica la pobreza, la cultura de la violencia, el ejercicio del poder, el carácter moral, la educabilidad, el potencial humano, el trato diferente por razón de género, los prejuicios, etc.

Ahora bien, intentar explicar que los negros, los blancos o los asiáticos, tienen distintos niveles de desarrollo intelectual, social y civilizacional, debido primariamente a su trasfondo genético, es incurrir en un reduccionismo antipático para los investigadores sociales. Tal modelo explicativo parecería equivaler a nazismo. A juicio de muchos, recurrir al modelo explicativo del "reduccionismo genético" se prestaría para darle visos de apoyo empírico muy conveniente a teorías eugenésicas y racistas del pasado.

No hace mucho se pensaba que conductas como el homosexualismo y el lesbianismo eran socialmente aprendidas y que, por lo tanto, se podrían modificar mediante la disciplina social-familiar, conversión religiosa, terapias psiquiátricas o mediante castigos sancionados por el código penal. Ahora parece haber pistas que sugieren la posibilidad de que sean los genes los responsables de estas conductas. De hecho en su obra Living with our genes, el Dr. Dean Hammer, psicólogo molecular (y a quien se atribuye la identificación de los genes que inducen al comportamiento homosexual) afirma lo siguiente: "El ambiente importa, desde luego, pero contrario a la creencia popular, los factores ambientales más importantes no son la crianza, la educación o el status social. Realmente son aquellas experiencias al azar e incontrolables tales como la precisa concentración de químicos particulares en el cerebro,o algo aparentemente de menor importancia, como puede ser un caso de sarampión infantil",

Conductas como las asociadas a la paranoia y la esquizofrenia parecían más el producto de patologías sociales y no genéticas. La presencia en el hogar de una madre castrante, el adiestramiento riguroso temprano en los hábitos de higiene personal, la timidez, ciertas experiencias de la etapa oral, anal, o de la etapa genital normal, etc., se aducían como experiencias responsables de conductas compulsivas y psicóticas en las personas. Si el reduccionismo genético, un paradigma que estaba en vías de extinción, se reestableciera como modelo explicativo oficial, ello nos obligará a investigar las bases genéticas para conductas semejantes. Incluso, se sugiere por algunos que parece haber cierta base genética para la conducta adictiva (a lo que sea). Luego, si a un grupo significativo de españoles, chilenos, puertorriqueños y cubanos, son adictos al tabaco y al alcohol, la culpa la tienen los genes. De ser cierto tal presupuesto, habrá que organizar sociedades de «genes anónimos», en lugar de alcohólicos y adictos anónimos.

Si se adoptara ese paradigma reduccionista, toda la vanidad filosófica de la autodeterminación y del libre albedrío de la cultura occidental, se esfuma ante la sospecha creciente de que no puedo evitar ser como soy. Sartre no podrá decir que estamos «condenados a ser libres», a no ser, claro está, que en

\footnotetext{
Hammer D, Copeland P. Living with Our Genes. New York:
} Anchor Books-Random House; 1998. 
Valuación bioética del proyecto "genoma humano" - L. Santos y Vargas

adición a los genes de la esperanza tengamos los genes de la libertad (lo que nos llevaría al juicio contradictorio de que estamos predeterminados a no estar predeterminados). Si soy culpado de conducta agresiva, podré organizar mi defensa legal mediante la identificación de los marcadores genéticos en mi genoma que me indujeron de modo inevitable a la agresión. La doctrina jurídica de imputabilidad de culpas por conducta alevosa y premeditada, no tendría base alguna. Como consecuencia, se desplomaría buena parte de las premisas del sistema judicial que exigen responsabilidad a quien no puede evitar los actos por los que se le sanciona. Contrario a Dostoievski, no habría ni crimen ni castigo.

Pero si las conductas que asociamos con la maldad son genéticamente inducidas ¿por qué no aceptar que la bondad, así como el respeto a las leyes, serán producto también de mis genes buenos, mis genes de la bondad y mis genes de la justicia? Es decir, lo que identificamos como "bueno" o "malo" escaparía a nuestra capacidad de conducta elegida, por lo tanto, no tendría sentido hablar de elegir la "vida virtuosa" de un buen ciudadano. Los premios y castigos serían lógicamente indefendibles, a no ser que nuestra preferencia por castigar y premiar sea otra conducta refleja genéticamente determinada, un truco astuto de los genes para hacer la vida social viable.

Llevando hasta el absurdo estas reflexiones, habría que preguntarnos si hay secuencias de genes que nos inducen hacia las conductas democráticas, aristocráticas, anarquistas, etc. En este contexto de ideas, los científicos de la conducta (como el psicólogo, el economista, el científico político, el antropólogo cultural), deberán integrar la visión genético-molecular a la visión macro social para articular una comprensión más cabal de los resortes varios que caracterizan la conducta del homo sapiens.

\section{Implicaciones para una nueva antropología filosófica}

Si bien es cierto que los avances del PGH prometen muchas opciones para combatir la posibilidad misma de la enfermedad y preservar la vida humana, no es menos cierto que la información que finalmente se obtenga de los estudios futuros, aportará claves mucho más intrigantes para replantearnos ciertas cuestiones filosóficas (al momento, quizás altamente especulativas, pero no menos importantes para la humanidad pensante.)

Una primera reflexión me sugiere que las interpretaciones construidas por la religión y la metafísica acerca del origen de la vida, y que aún están vigentes en buena parte de la cultura humana occidental, sufrirán una revisión radical. Moisés y Platón, así como San Mateo y San Juan tendrán que vérselas con Darwin y con los biólogos moleculares, quienes parecen haber dado al fin con el secreto de la evolución y devenir humanos. Los detalles que gradualmente se darán a conocer por el PGH tendrán un efecto tipo Big Bang en el sistema de creencias heredado, y en las explicaciones producto de la especulación filosófica más granada. La explosión epistemológica que propiciarán las investigaciones futuras de la biología molecular quizás reinvindiquen los alegatos de la nueva disciplina de la socio-biología. Según ésta, los modos sociales de conducirnos y organizarnos hay que entenderlos como el resultado de los recursos de que se ha valido la evolución biológica de la humanidad. El ethos humano, las creaciones intelectuales, las instituciones, así como la naturaleza y cultura humana, no serían explicables como el producto de un logos absconditus, sino como el resultado de una especie de marrullería y astucia ínsita en el proceso de millones de años de la evolución que han hecho posible la vida en el planeta. Algún gen saltarín produjo una 
mutación accidental, en virtud de la cual se forma la especie humana, mutación que a lo largo de los eones ha demostrado ser funcional y lo suficientemente adaptable como para, entre otras cosas, capacitar a la especie a mejorarse a sí misma.

Aquellos que creían firmemente que había una diferencia esencial entre la especie humana y las otras especies vivas tendrán que reconciliarse con el dato humilde de que los chimpancés y nosotros compartimos, entre otras características, aproximadamente el 97.3 de la información genética. Es decir, apenas un 2.7 $\%$ separa nuestra naturaleza biológica de la de estos simpáticos simios. De hecho, se afirma que los chimpancés están genéticamente más cercanos a los humanos que a los gorilas. Los hallazgos del PGH (hasta el momento) no permiten afirmar que estamos tan cercanos potencialmente a los ángeles, o a los demonios, como reza el discurso acerca de la dignidad humana de Pico della Mirandola.

Entre otros datos interesantes se informa, además, que la diferencia en la información genética entre un ser humano blanco, uno negro y otro asiático puede que sea de apenas un . $10 \%$. Un dato que nos hará sentir más sobrios aún, es el hecho probable de que la diferencia entre la información genética de las ratas y nosotros no sobrepase de un 10 a un $20 \%$, debido probablemente a diferencias en la secuenciación y cartografiado del mapa genético respectivo (y no a una alegada esencia espiritual exclusiva de nuestra especie). En ese contexto es más racional afirmar que las diferencias entre los seres vivos son más de grado que de naturaleza esencial. Sólo nos distingue una diferencia de configuración en la información. Ni siquiera somos más complicados en número que otros habitantes de la comunidad biótica: la mosca frutera tiene unos 13000 genes, el gusano C. Elegans tiene unos
18000 , la planta de mostaza unos 26000 . Compare ese número con los cerca de 26000 genes que, aproximadamente, tiene el genoma humano (según el Dr.Craig Venter, fundador de Celera Genomics) o los cerca de 40 000, según los investigadores de las agencias estatales estadounidenses participantes. Incluso, se informa que se han encontrado unos 200 genes bacterianos que se colaron en algún momento de la evolución en nuestro ADN. (Repito: no se han encontrado genes de ángeles o demonios por ningún lado del genoma).

La soberbia de creernos que somos la imagen de algún dios, no parece ser corroborada por la información genética. Si se fuera a reescribir el Génesis hebreo a la luz de estos hallazgos (incompletos aún), habría que decir «En el principio era la información» y ésta se fue organizando por puro accidente. Una vez que se complete el PGH, y se realicen las futuras investigaciones que serán necesarias para descifrar exactamente qué significan y cómo correlaciona un gen o aspectos multifactoriales genéticos con la naturaleza humana, habrá que concluir que somos información. Somos información química que sirve de sistema operativo para que corra en nosotros el programa cultural construido, a su vez, con la información lingüística de la cultura en que nacemos. Nuestra humanidad no sería otra cosa que el encuentro feliz de la información biogenética con la información cultural que nos configura. Tendrá mucho sentido afirmar que la conjugación de las letras de la gramática química (adenina, guanina, citosina y timina) interactúan con los distintos alfabetos humanos para construir eso que llamamos ser humano, persona, ciudadano.

Comprensiblemente, a muchas personas les aterran las implicaciones potenciales que para sus creencias se podrían desprender de las investigaciones en torno al genoma humano, vegetal y animal. Por razón de las experien- 
cias de aculturación que han conformado sus motivos y resortes emocionales, estas personas insistirán en afirmar sus creencias, pues necesitan más de la seguridad de sus certezas que de la claridad explicativa de la ciencia. Ante el riesgo de que zozobren sus creencias, muchas personas e instituciones se inclinarán a negar la verdad de los nuevos datos, ya que perciben que sus certezas están amenazadas. Tal reacción es comprensible (¿tendrán una base genética tales reacciones? ¿Habrá algún gen de la esperanza que les induce a negarse a abandonar esa emoción socio-biológicamente trabajada?). Cuando se ha vivido desde hace siglos en la comodidad de las certezas que nutrían nuestro ego especista, la inercia intelectual y emocional se constituye en un verdadero bloqueo para enfrentar explicaciones alternativas. En este punto, quizás conviene hacer una distinción. Las creencias de la ciencia sólo se afirman ante la evidencia, mientras que otras creencias pueden sostenerse en ausencia de evidencia (como es el caso de la religión), y más extremoso aún, hay quienes afirman sus creencias a pesar de la evidencia en contra (lo que explica la conducta fanática).

Aunque algunas iglesias establecidas (como la Iglesia Católica y ciertas organizaciones de persuasión protestante) han expresado que no le temen a la información y los resultados a que pueda conducir el PGH, no es de extrañar que íntimamente estén sobresaltados. Por menos de lo que insinúa el PGH, la Santa Inquisición quemó en la hoguera a Giordano Bruno en el siglo XVI; por menos que eso los sabios de la Iglesia obligaron a Galileo Galilei a retractarse de sus doctrinas astronómicas en el Siglo XVII, pues las explicaciones del famoso astrónomo contradecían el dogma oficial respecto al ordenamiento del universo. El mismo René Descartes tuvo que refrenar metódicamente su duda metódica para evitar ofender a las autoridades eclesiásticas de su tiempo.
No es para menos. Con sobriedad y humildad tenemos que admitir que los humanos, los simios, los gusanos, la Drosophila y los vegetales tenemos un mapa genético respectivo que difieren entre sí por la cantidad de información genética que contienen y por la distinta secuenciación de los genes en el mapa genómico respectivo.

Apurando el análisis hasta sus últimas consecuencias lógicas, cada vez más parece corroborarse la premisa filosófico-escéptica de que somos más bien el producto de un diseño surgido del azar y no el diseño deliberado de una inteligencia creadora. Es la conclusión que «se cae de la mata» filosófica. Desde luego, esto no disminuye la grandeza del fenómeno de la vida humana. Por el contrario, nos asombra constatar cómo este azar que se llama persona se ha encumbrado a través de formas culturales creadas por su inteligencia para colocarse en un lugar cimero en la escala evolutiva de la vida.

Si partimos de la conclusión obvia que sugieren las reflexiones anteriores (que somos el producto de la configuración y reconfiguración al azar meramente de la información bioquímica y cultural, a lo largo de millones de años), es de esperarse que la ciencia pueda explicar algún día cómo es que ocurre el fenómeno de la conciencia. Es decir qué es lo que ocurre bioquímicamente en el hecho de que yo me doy cuenta de que me doy cuenta. ¿Cómo explicar, desde la interacción de los genes, que en este instante, mientras escribo, yo estoy consciente de que estoy reflexionando y escribiendo acerca de la conciencia humana como un fenómeno explicable físicamente? Éste es uno de los retos más apasionantes de la genética del futuro porque, después de todo, la grandeza que nos hemos atribuido los seres humanos, como si fuéramos señores del universo, radica precisamente en esta facultad o actividad cons- 
ciente, en este darme cuenta de que me doy cuenta de que nos damos cuenta. Muchos crédulos de explicaciones metafísicas no han querido darse cuenta de esta nueva antropología filosófica. El Proyecto del Genoma Humano demostrará que, después de todo, sólo somos humanos, es decir, el resultado afortunado de la interacción de la bioquímica con la cultura. Demostrará también que la ciencia no es un asalto al espíritu humano sino que la curiosidad y los logros científicos constituyen una de las expresiones más elevadas de ese espíritu.

\section{Bibliografía}

Annas G. Gene Mapping: Using Law and Ethics as guides. New York: Oxford University Press; 1992.

Davies K. Cracking the Genome: Inside the Race to Unlock Human DNA. New York: The Free Press; 2001.

Hammer D, Copeland P. Living with Our Genes. New York: Anchor Books-Random House; 1998.

Jonas H. Técnica, medicina y ética: la práctica del principio de responsabilidad. Barcelona: Paidos; 1997.

Martínez SM. Manipulación genética y derecho penal. Buenos Aires: Editorial Universidad; 1994.

Mayr E. Toward a New Philosophy of Biology: Observations of an Evolutionist. Massachusetts: Harvard University Press; 1988.

Murphy T. Mapping the Human Genome. En Kuhse H, Singer P, eds. A Companion to Bioethics. U. K.: Blackwell Publishers; 1998: 198.

Ridley M. Genome: The Autobiography of a Species in 23 Chapters. New York: HarperCollins; 1994.

Wingerson L. Mapping Our Genes: The Genome Project and the Future of Medicine. New York: Plume Books; 1990.

Zweiger G. Transducing the Genome: Information, Anarchy and Revolution in the Biomedical Sciences. New York: McGraw-Hill; 2000. 